\title{
The Cultural History of the Corset and Gendered Body in Social and Literary Landscapes
}

\author{
Melis Mulazimoglu Erkal \\ Ege University, Turkey
}

\begin{abstract}
This study centers on the significance, uses and changes of the corset in the Western culture and literature through a study of body politics, culture and fashion. The emplacement of corsetry in the West as an undergarment goes back to $1600 \mathrm{~s}$. Research shows that the study of corsetry is important as the corset has been a permanent, pervasive, popular object preferred mostly by women from different classes, sometimes by men and even children since the Middle Ages. Moreover, it is important to notice how the corset has gone beyond its use value and has become first a symbol of rank and elegance, then of female oppression and victimization and finally a symbol of sexual empowerment and feminine rebellion in contemporary time. Popular critics of the field state that the corset today is far beyond its earlier restrictive usages and negative meanings as the garment today has become a favored item in fashion industry and preferred by celebrity icons all around the world. The corset at present is an outerwear, art object and ideological construct. So, what makes the corset so popular and everlasting? The study on corsetry yields to a critique of Western culture from socio-political perspective as well as through body politics and gender studies. In that respect, this work aims to explore how corsetry in past and contemporary time exists as an essential part of patriarchal ideology, influencing social and literary landscapes and borrowing from the beauty aesthetics, thus creating the idealized feminine of each century.
\end{abstract}

Keywords: Corset, body, gender, fashion, culture, ideology.

\section{Introduction}

As Elizabeth Wilson (2003) claims, clothes represent the mood of each succeeding age and what we do with our bodies express the Zeitgeist (47). In a similar way, Roland Barthes talking about the dynamic relationship between dress, body and culture, argues in Language of Fashion (2013) that fashion is a social text to be read and the fashioned body has its signs in certain rhetoric. In that respect, corsetry can be claimed as one of the popular garments of a social condition and the prevailing sign of a specific fashion. Additionally, this study centers on the significance, uses and changes of the corset in the Western culture and literature from its early usages up to contemporary time through the politics of body and fashion. In that way, the study of corsetry is aimed to unveil the ways ideology co-operates with fashion to define the beauty standards and help create the idealized (female) image as a cultural construct in Western society.

The corset has been a permanent item of clothing since the Middle Ages. It has been used as an undergarment, outerwear, fetish object and eventually has become an art object at present time. The corset, a construction of steel, whale bone and silk, was used mostly by women, sometimes by men and even by little children in order to discipline the (female) body, improve physical appearances, correct physical deformations and help enhance social status in society while restricting, silencing and punishing the body from childhood to old age. Despite the negative effects of the garment, women continued to wear corsets. The reason for the popularity of the corset perhaps owes to the symbolic meaning it represents. Corsetry, points at the dichotomy between power and restraint ideologically enacted upon the female body. That is why it stands between elegance and repression, empowerment and victimization. The positive and negative connotations of corsetry in the history of Western culture and fashion are put forward in the exemplary theoretical books by Valerie Steele, the chief curator and acting director of The Museum at the Fashion Institute of Technology, New York. In her books, The Corset, $A$ Cultural History (2001) and Fetish: Fashion, Sex and Power (1996) Steele argues that the corset is probably the most controversial garment in the history of fashion. Throughout its history, corsetry is believed to have functioned as a coercive apparatus through which patriarchal society controlled women and exploited their sexuality (Steele, 2001, p.1-2); however, as Steele argues corsetry is far beyond these narrow frames as the popularity of the apparatus is long-standing and 
remarkable owing to its positive connotations such as beauty, youth, social status, etc. Going back to an earlier reference point, American economist and sociologist Thorstein Veblen has argued in his famous work The Theory of the Leisure Class (1899) that the corset in economic theory is a mutilation for the purpose of lowering the subject's vitality and rendering her permanently unfit for work. The corset impairs the personal attractions of the wearer, but the loss suffered on that score is balanced by the gain which comes of her visibly increased expensiveness and weakness. Likewise, the historian, curator and author Leigh Summers in her work, Bound to Please (2001) asserts that the garment's longevity depends on the role of corsetry in paradoxically sexualizing the female body, while working to contain and constrain it:

However, the corset did not always implicate commodified female sexuality and restricted gender roles. Women were not always helpless victims in their corseted bodies, but were agents in the construction of their own sexual subjectivity [...] Corsetry empowered women to behave within existing social constructions of femininity and enabled them to manipulate/change those constructions to their own social advantage (Summers, 2001, p.5, 126).

Especially in the late nineteenth century, tight-lacing indicated status and privilege; the women were regarded as purer, well mannered and more pious as much as they were tightly-corseted. Due to Victorian codes of morality that viewed women as submissive, fragile and chaste, stricter forms of corsetry were preferred by upper-middle class women because looser forms of dress meant loose woman, who was considered to be improper and immoral however, it was also popular among working-class women who had to prefer a "loose" corset that would not hinder them from hard work.

The depiction of woman through dress was also reflected in numerous nineteenth and early twentieth century literary works, in which corseted body existed as a sign of feminine beauty, fragility and entrapment. This study aims to include particularly American examples such as Henry James' The Portrait of a Lady (1881), Edith Wharton's The House of Mirth (1905) and The Age of Innocence (1920); Amy Lowells' Patterns (1917) and Margaret Mitchell's Gone with the Wind (1936), to name only a few. All these works, among many other sub-plots they handle, make emphasis on dress codes and represent the corseted body both in restricting and liberating contexts that help women construct their identity and position in society.

Construction of femininity via dress varied from one decade to another. And so did the shape of the corset. New forms of corsetry were used to reflect the idealized female image different in decade such as the divine Virgin Queen, the loose Marie Antoinette, the chaste Victorian woman, the Southern Belle, the Bloomer, the New Woman, the Gibson Girl, the Flapper and etc. For instance, the sixteenth century corsetry was a strict $V$ shaped one whereas the late eighteenth century favored a looser one known as the Empire Silhouette. The nineteenth century corset represented the hourglass body figure contrary with the S shape corset of the Edwardian period popular with the idealized feminine images like the New Woman and the Gibson Girl; and eventually more liberating dress codes with looser forms of corsetry emerged with the Flapper type of woman in the 1920s. However, in the Post WWII period, stricter forms were favored again with emphasis on the tiny waist, leading to no corsetry at all in the next decade of the 1960s. This change was closely linked with transformations in the Western society in terms of economic and cultural formations such as the development of capitalism and emergence of woman suffrage movement, to name only a few.

\section{When corsetry is observed in today's Western world, it is true to say that the garment has surpassed its earlier usages both in meaning and style. Thanks to iconic fashion designers Vivienne Westwood, Jean Paul Gaultier, Thierry Mugler and Alexander McQueen to name a few, corsets are still used in their original forms but have been applied to contemporary fashion in extraordinary contexts. As stated in The Corset in Late 20th-Century Fashion:}

The result was both as artistic and theatrical; corsets would become armor for a late 20th-century cyber-woman out of a science-fiction cartoon. The corset had become an 'objet d'art', with a new meaning, it was no longer the symbol of women's oppression, the corset had become a symbol of sexual empowerment [...]The corset, still being a historical garment, probably gives the wearer the feeling of timelessness and freedom felt when wearing fancy dress. It lets her adopt a role, a character, maybe a powerful seductress, which is not allowed during daily life. It is also a reminder of an idealized past, pictured in Toulouse-Lautrec's paintings and in the movie Moulin Rouge (2016, Victoria and Albert Museum Archives).

In this light, this work is intended to discuss the significance of the corset in a variety of contexts from social life to literary landscapes in a diachronic way. The study is a dynamic body of work as the nature of corsetry is shaped by changing cultural trends, ideological enforcements and consumerist practices in Western culture. The corset, once a killing machine designed to discipline the body, then a symbol of rank, female elegance and chastity, sometimes a symbol of eroticism and sexual empowerment, lately an art object, has become a flexible medium appealing to a wide range of audiences regardless 
of age, gender, race and class. Thus, the study aims to examine the interaction between body, culture and fashion through the lens of cultural studies practices.

\section{Historical Background}

The origins of the corset are unknown; but it is often argued that corsetry began in the ancient world such as Greece or Minoan Crete. Alternatively, the first corset making its appearance in the Western world belongs to a particular European aristocrat, Catherine de Medici (Steele, 2001, p.2) who was believed to wear corsets made of metal, "a tortuous device of steel" in the sixteenth century. The corset, in general terms, stressing on "slender or tiny waist line" controlled and restricted the female body for centuries. It was mainly used to reduce the waist line to 17-20 inches $(43-50 \mathrm{~cm})$. According to Pauline W Thomas (2001-2014), the corset was first made of iron, whalebone and then of other fabrics; it shaped the body conically with rigid backs and flattened breasts or rounded hourglasses with curved shoulder.

Tight-lacing had several pitfalls such as pregnancy complications due to compression of the womb, miscarriages during pregnancy, deformed childbirth, indigestion and constipation, liver and lung diseases such as pneumonia and tuberculosis, headache and poor appetite, cold hands and feet and even red noses, fainting at the balls, inability to breathe, move and walk comfortably (Kiter 2016; Summers 2001, p.89-90, 116).As reflected by Summers (2001), despite these negative claims made by doctors and feminist critics on the dangers of tight-lacing, women continued to wear corsets because,

The fading female with red lips and pale skin was a popular target of marriage. It was also a sign for tuberculosis which made females more fragile, weak and thus more feminine. For that reason, tuberculosis was considered as a good or beautiful death which resulted in the romanticizing of the condition (Summers 2001, p.19-20, qtd from Showalter 1985).

However, according to Kiter (2016), as the nineteenth century progressed, a number of manufacturers began offering "Health Corsets", "Sporting Corsets" and even "Pregnancy Corsets" as alternatives to the unforgiving "stays." These less restrictive garments were designed with elastic panels, cotton netting and ventilation for more comfort and freedom of movement (Kiter, 2016). Corsetry was not restricted to females only; it was a popular garment of clothing for males and children as well. For female children corsetry started at the age of 9 or 10 to have a perfect body when they grow up. The mission according to Summers (2001) was to achieve sexual desirability in young girls and at the same time deny or repress sexual desire in the bodies. Males, though rare, used corsetry for reflecting a fashionable style and proper posture in a stronger, stricter body (p.80-81).

In the Western world, mostly in the sixteenth and early seventeenth century Elizabethan society, corseted body was a sign of divine power and strength. A stiffed V shaped model was used on top of the dress, hiding women's feminine appearance and focusing more on the divine implication of the female body. This was largely because of the Virgin Queen Elizabeth l's common perception among her people: God-like authority, power and strength rather than feminine beauty and female fragility (Thomas, 2001-2014).

However, in the early eighteenth century, women were portrayed within highly decorative dress codes underlining luxury and ornamentation as the Enlightenment rationality was rather a masculine domain. Female body was hidden under layers of heavy clothing and restrictive corsetry (Thomas, 2001-2014). Early eighteenth century corsetry added a decorative platform that made hips look larger enough to carry a tea tray on them. That was why the corset shape was called the "Tea Tray Corset."The image emphasized on rectangular shapes in parallelism with the era's interest in geometric shapes. It was almost impossible for woman to walk and sit properly in these corseted forms. As the corsets expanded in a horizontal way, women were restricted to great extent; the only way for women to go through the door was to go sideways (Glasscock, 2004; Victoria\&Albert Website, 2016). Catherine Spooner (2004) argues that in the late eighteenth century (1790s) women fashion in Europe was revolutionized by the sudden decline of corset as Marie Antoinette introduced the "Chemise Dress" for her daywear. It was a loose long undergarment usually worn as underwear; however, she wore it as outside dress without any corsetry. Chemise dress symbolized the queen's rebellion against traditional political and gender roles. Thus, the loose chemise dress reflected Marie Antoinette as a political threat. This was seen as a sign of decadent aristocracy and soon the chemise dress, along with the "Empire Silhouette" would be somehow completely overthrown (Werlin, 20102017).

The nineteenth century was mainly remembered and thus named after Queen Victoria and her 70 years reign in Britain (Johnstone, 2016). The cult of domesticity was the popular discourse of the era; modesty, piety, passivity, fragility were the expected feminine features. Victorian Era was the period when subjection of women was obvious as women were quite 
restricted; they were able to express themselves mostly in private spaces and through their corseted bodies. Thus, midnineteenth century (1830-50s) corsetry emphasized on the "Hourglass Figure"; tiny waist, exaggerated shoulders and hips, pointing to the "ideal" feminine figure known as the "Southern Belle" with the use of crinolines and caged corsets (Thomas, 2001-2014, Johnstone, 2005). In short, Victorian corsetry working together with Victorian morality, repressed the female body and feminine identity both in and outside home. In other words, nineteenth century hourglass figure underlined the division between public and domestic spheres of life (Bordo, 1993). However, in the 1850s, the American Southern Belle had to confront with the "Bloomer", a reformist type of dressing style and that of female identity related to the American feminist and activist Amelia Jenks Bloomer who was a leading figure in woman's liberation at Seneca Falls. Amelia Bloomer along with Elizabeth Cady Stanton and Susan B Anthony started wearing these radical trousers under their dresses in a new liberated fashion, which was not long-lived but at least allowed space for women in public platforms and no corsets were needed.

Moreover, with the emergence of a new type of female identity known as the "New Woman" in the late nineteenth century, tight-lacing was reduced to some extent. The term, "New Woman" was first used by the feminist activist and writer Sarah Grand in her article "The New Aspect of the Woman Question" (1894) in which she tried to handle womanhood issue at a time of great social change in the fin de siècle British society. Later on the term was popularized by the American writer Henry James in most of his fiction. As explained by Roberts (2017):

New Women were feminist, educated, independent career females in Europe and the United States. Independence was not simply a matter of the mind. It also involved physical changes in activity and dress, as activities such as bicycling, tennis, horse-riding expanded women's ability to engage with a broader more active world. They also paved the way for the militant Suffragettes of the 1900s. The 1870 Education Act allowed women both to vote and to work (Roberts, 2017).

The New Woman helped transform woman's perception of corsetry from rigid forms to a more liberating design yet it was not able to confront with the Victorian legacy completely and was still shaped by the patriarchal sensibilities of its time. The forth-coming decade, known as The Gilded Age (1870s-1900s) in Americal the Edwardian Age (1900s) in England was a period of optimism and prosperity. So, the period emphasized on the "S figure corset", stressing the once romantic Empire Silhouette that was missing. Contrary with the New Woman corsetry, females in the 1900s were corseted as tightly as they had never been before (Thomas, 2001-2014). It is said that one reason for the restriction of female body through the use of corsetry might be that women liberation movements had peaked so now that women were getting stronger politically, they had to be restricted physically. This idea in a similar way is better explained by the contemporary feminist critic Naomi Wolf (2002) who argues that the more legal and material difficulties women have broken through, the stricter and cruel images of female beauty have come to force women. As women released themselves from the cult of domesticity, the beauty myth took over either with new practices or through the struggle to create a nostalgic past of good old days when women were treated merely as objects (2002, p.10). The "Gibson Girl" was one of those beauty myths focusing on the idealized female identity popular between 1890-1910. Originally a caricature created by the American artist Charles Dana Gibson, the "Gibson Girl" was used to satirize the New Woman who was sportive, emancipated and strong (Thomas 20012014). On the other hand, the Gibson Girl was every man's dream girl, attractive, slender, respectable, perfectly dressed and tightly corseted.

War had an ambiguous effect on tight-lacing. In Post WWI period, women almost stopped using corsetry on the other hand; post WWII saw the rise of corsetry once again. The 1920s introduced the "Flapper" type, young, rebellious, free, middleclass women who partially got rid of their corsets. Now that women got the right to vote, they also broke free of the restricted codes of clothing (Thomas, 2001-2014). Yet, this did not last long. Again restricted codes of femininity were forced upon females through the myth of domesticity in the Post WWII period which was a period of recovery from the war. The era stressed on stability and family. Emphasis on the corseted feminine figure was a sign that women should give up labour which they had undertaken from their husbands when males were at war. The effort was to re-structure the sweet household that belonged to women. In order to achieve the ideal family life, an ideal female was needed and it was reshaped by the clothing devices that constructed female identity (Bland, 1983). This change in social structure and clothing explains the feminist critic N Wolf's argument who claims that beauty is a currency system like politics and the beauty myth is not about women at all. It is about men's institutions and power (Wolf, 2002, p.13). Additionally, Dior's New Look defined the Post WWII Fashion with its popular corsetry, known as the waspie (Victoria\&Albert Museum Archives, 2017).

The 1960swere the times when women, triggered by feminist activists of the counter-culture movement, burned their bras. It was the first time when women stopped using corsets. However, in the mid-1970s, corsets became popular again. As 
stated in The Corset in Late 20 $0^{\text {th }}$ Century Fashion, fashion designer Vivienne Westwood used corsets in their original forms but applied them to contemporary fashion. J P Gaultier's corsets became iconic when Madonna wore one during her worldtour in 1990. This was the first time corsetry was used outside its usual context. The corset thus became an art object, with a new meaning; it was no longer the symbol of women's oppression, but a symbol of sexual empowerment, sometimes a fetish object or sign of subculture attitude (Victoria\&Albert Museum Archives 2016). The 2000s were eclectic times when corsets appeared in myriad ways and with numerous definitions. Corsetry prevailed both in theory and practice all around the world. Although it was not a necessity of woman's clothing any more, the garment made widespread appearance in the Western world. Blogs on wearing/making/selling corsetry, corsetry conferences and symposiums, catwalks with corset themes and streets with corseted celebrity bodies were noticed everywhere. However, the corset in its contemporary meaning has gone beyond its traditional usages. Firstly, it is not a necessity. Secondly, rather than stressing on the subjection of female sexuality and victimization, the corset emphasizes on female empowerment, authenticity or sub-culture behavior as the garment is now practiced in radical ways; for example, in the form of body tattooing or as a part of subculture fashion such as gothic Lolita fashion, etc. Thirdly, the corset has been demystified; it has been taken out if its traditional context and put into consumerist practices via the haute couture touch of contemporary fashion designers. In a way, the corset itself has mainly become an art object to be sold and purchased unlike its earlier usage that stressed on the commodification of female body. In short, this shows the final stage in the corset's transformation from its early usages up to contemporary time in the West.

\section{Theoretical Background}

The corset, on a critical base, is related to body politics which in turn borrows from feminism, fashion politics and cultural studies. For this reason, in this section the corset will be studied through the lens of some feminist critics, fashion theorists and cultural studies practices.

We have said in the opening section that there is a multi-dimensional relationship between body, fashion and culture. According to Entwistle (2001), the body and dress operate dialectically: dress works on the body, imbuing it with social meaning while the body is a dynamic field which gives life and fullness to dress (Entwistle, 2001, p.43; qtd from Entwistle and Wilson, 1998).In that respect, the corset has worked as a necessary part of woman's fashion borrowing from culture and ideology in order to shape the body. As Summers argues, the corset disciplined and contained the "Western" body and acted as a symbol of civilization and order as opposed to the disorder of the primitive naked bodies (Summers, 2001, p.19). As for the "female" body, the corset and its related devices such as the crinoline, the bustle, the girdle, the pannier and the push-up bra have been life-long companions for women all around the world (Summers, 2001, p.4). According to Young (1980), this is because of the changes in social and political life, cultural trends, ideological enforcements and consumerist practices in Western culture which determines the uses and shapes of the corset leading to restrictions (Young, 1980, p.150-151). That is why different types of corsetry have been used to define the idealized female image popular in each decade.

Marion Young claims that women's empowerment and disempowerment are socially constructed. Similarly, David Kunzle in his Fashion and Fetishism (1982), argues that female sexuality is a socially manipulative, subversive force and it has been severely repressed by male authority. Likewise, Irigaray in her Speculum of the Other Woman(1985) concerns how Western culture expresses a masculine desire in silencing the female. Furthermore, feminist critic Iris Marion Young (1980)asserts that, female body is often considered as docile, "manageable", useful and normal (p.136). In a similar way, Foucault in Discipline and Punish (1975) argues that individuals are under constant surveillance and regulation in ways that are often invisible, leading to normalization and acceptance of such systems. Docile body shows how individuals in their bodies/environments are subject to regulations, transformations, and improvements. In this context, body is regarded as the site of regulation and target of power. In hegemonic masculine social-space, corsetry is a significant device of clothing reinforcing this idea. Throughout its history, the corset is believed to have functioned as a coercive apparatus through which patriarchal society controlled the female body and exploited women's sexuality, but at present time, the corset has moved far beyond these narrow claims (Steele, 2003, p.1). The corset did not always implicate commodified female sexuality and restricted gender roles. Women were not always helpless victims in their corseted bodies, but were "agents in the construction of their own sexual subjectivity" (Summers, 2001, p. 5). Corsetry empowered women to behave within existing social constructions of femininity and enabled them to manipulate/change those constructions to their own social advantage (Summers, 2001, p.126).So while the corset is seen by some feminists (Roberts,1977) as a garment setting out to discipline the female body and make her docile and subservient, an exquisite slave, Kunzle (1982) has argued 
in relation to female tight lacers that these women were not passive or masochistic victims of patriarchy, but socially and sexually assertive (Kunzle, 1982). In a similar way, Summers indicated that corsetry operated as a powerful and multifaceted signifier of both transgressive and normative femininity in different contexts (Summers, 2001, p.7). For instance, middle-class women wore corset to strengthen and protect their class hegemony while working class women corseted to escape their class origins with the hope of entering the world of their betters (Summers, 2001, p.10).

The use of corsetry at present time can be explained in terms of post-feminist ideas borrowing from the contemporary feminist critic Naomi Wolf (2002) who claims that the corset now is replaced by the new control devices of patriarchal culture such as plastic surgery, diet and extreme physical exercise. This shows that Western patriarchal culture still has a lot to shape and correct, deciding what it is beautiful, proper and accepted and what is not. This is an example of how cultural "representations homogenize" and how "these homogenized images normalize" women (Bordo 1993, p. 166). However, as the contemporary use of corsetry is more dynamic and eclectic than it has been before, I argue that the device helps create varied subject positions in a certain "habitus" where dress exits as a lived practice, freed and at the same time determined by oppressive forces (Entwistle, 2001). From that angle, the body goes beyond a passive one and the corset rather than a tool for surveillance, participates in creating subject positions, subversive or not. As Entwistle (2001) quotes from P Bourdieu in her work,"habitus yields a more dynamic theory of embodiment. Bourdieu provides an account of subjectivity which is both embodied, unlike Foucault's passive body and his technologies of the self and which is active in its adaptation of the habitus. As such, it enables an account of dress which does not fall into voluntarism and assume that one is free to self-fashion autonomously" (Entwistle, 2001, p.57-58).

\section{Literary Depiction of Woman through Dress}

Looking at dress, I argue that the generational categorizations of the idealized female image such as the Victorian Woman, Southern Belle, Bloomer, New Woman, Gibson Girl and the Flapper help us understand the changing socio-political dynamics that determine how one culture views woman. Through these labels, it is interesting to see how fashion cooperates with ideology to determine what is to be ideal, true and perfect for the female in each decade and how standardization relies on stereotypical gender norms cultivated by fashion. Thus, this section aims to look at the depiction of the idealized female image in American society with examples from American literary tradition such as Henry James' The Portrait of a Lady (1881), Edith Wharton's The House of Mirth (1905) and The Age of Innocence (1920), Amy Lowell's "Patterns" (1917), F Scott Fitzgerald's The Great Gatsby (1925) and Margaret Mitchell's Gone with the Wind (1936).

American writer Henry James's famous novel, The Portrait of a Lady (1881) focuses on the life of a young woman, Isabel Archer who is torn in-between her wrong choices and her expectations in life. Inheriting a large amount of money and not knowing what to do with it, she falls victim to her suitors' plans for controlling not only her inheritance, but also her life, identity and body. I argue that the success of the work lies in James's amazingly detailed depiction of womanhood, female sexuality and feminine body through the heroine's rigid clothes which restrict her, surround her and sometimes suffocates her. It is the 1870s and Isabel represents the domestic Victorian lady whom she does not want to become. She wants to break through society restrictions forced upon her gender however, as she is embedded with Victorian morality, she cannot challenge what customs ask her to:

Nothing that belongs to me is any measure of me; everything's on the contrary a limit, a barrier, and a perfectly arbitrary one. Certainly the clothes which, as you say, I choose to wear, don't express me; and heaven forbid they should!"

"You dress very well," Madame Merle lightly interposed.

"Possibly; but I don't care to be judged by that. My clothes may express the dressmaker, but they don't express me. To begin with it's not my own choice that I wear them; they're imposed upon me by society."

"Should you prefer to go without them?" Madame Merle enquired in a tone which virtually terminated the discussion (PL, 1881, Vol I, Chp. 19).

s a free-spirited, intelligent, beautiful woman, who desires to experience life on her own; however, at some point, she is captivated by the charms of marrying the patriarch in a world where she eventually takes her place as an object of male desire. Through the end, Isabel chooses marriage and this leads to her entrapment in patriarchal society. The more she struggles to survive as a wife, the deeper she falls into frustration as a self. The ambiguous ending of the novel also stresses 
on Isabel's inability to decide between the two roles forced upon her: the angel in house or the mad, free woman in the attic.

Edith Wharton's The House of Mirth (1905) and The Age of Innocence (1920), portray the idealized female in a similar fashion. The House of Mirth (1905) focuses on Lily Bart, a well-bred however impoverished, romantic beauty who tries to get married to an upper-class male before she turns 30 . Wharton depicts the turn of the century "Gibson Girl" via Lily Bart who wants to break free of her destiny yet unable to succeed because of social pressures and conventions upon her. A dream girl whom everyone admires, Lily Bart exists as the idealized fragile female who is eventually drowned to suicide for not fulfilling what society forces upon her. Wharton portrays Lily "as the victim of the civilization which had produced her, that the links of her bracelet seemed like manacles chaining her to her fate" (Wharton, 1905, Book I Chp I). I argue that Lily represents the victimization of woman, confined by the items of exquisite luxury she inherits from her family of the leisure class, which also contributes to her status as an object of desire in American society. From the bracelet that shines on her arm to the corset and long skirt she wears, Lily exits as an adorable but useless ornament, unable to express herself freely. Similarly, Wharton in her other novel The Age of Innocence (1920), portrays Victorian society in the 1870s through individuals, married and unmarried; old and new. The novel focuses on Mr Archer's inability to decide between his pure love interest May and the passionate, free-spirited Mrs Ellen Olenska. Wharton portrays Mr Archer's inner dilemma through two contradictory female characters who are represented via their obedience to society norms, such as proper dress, proper marriage, proper attitude:

It was usual for ladies who received in the evenings to wear what were called "simple dinner dresses": a close-fitting armour of whale-boned silk, slightly open in the neck, with lace ruffles filling in the crack and tight sleeves with a flounce uncovering just enough wrist to show an Etruscan gold bracelet or a velvet band. But Madame Olenska, heedless of tradition, was attired in a long robe of red velvet bordered about the chin and down the front with glossy black fur. Archer remembered, on his last visit to Paris, seeing a portrait by the new painter, Carolus Duran, whose pictures were the sensation of the Salon, in which the lady wore one of these bold sheath-like robes with her chin nestling in fur. There was something perverse and provocative in the notion of fur worn in the evening in a heated drawing-room, and in the combination of a muffled throat and bare arms; but the effect was undeniably pleasing (Al, 1920, Part I chp. 12)

I argue that Madame Olenska, with her choice of dress has gone quite beyond society's expectations for a widow and seems unlikely to be accepted by the rest of the community, not only due to her extravagant taste of dress but also because of her improper, flirtatious behaviors in contrast with Victorian morality which highlights piety, purity and submissiveness in females. Madame Olenska is rarely accepted by the Victorian community however, this does not silence her. Although she remains as an outsider, her liberated spirit is reflected through her choices unlike pure and chaste May who yields to society norms in the expected manner. Thus, Wharton portrays through Olenska a female more ahead of her time, departing from the Victorian Woman to slightly becoming the New Woman type.

Amy Lowell's "Patterns" (1917) is a great work of poetry depicting the female frustration in patriarchal society through the use of dress. The persona, a young lady soon to be married, is waiting for her fiancé to come back from war, however with the unexpected arrival of a letter she learns that he can never fulfill his promise as he is now dead. Her unbearable rigid form of clothing confines the female persona as much as the fixed patterns of patriarchal society such as customs, war, marriage and etc. She feels trapped not only in her corseted body, but also by the institutions of society in the late-eighteenth century:

I walk down the garden paths, /And all the daffodils /Are blowing, and/ the bright blue squills/ I walk down the patterned garden paths / In my stiff, brocaded gown/ With my powdered hair and jewelled fan/I too am a rare / Pattern. As I wander down/ The garden paths/ My dress is richly figured/And the train/ Makes a pink and silver stain/ On the gravel, and the thrift/

Of the borders/Just a plate of current fashion/Tripping by in high-heeled, ribboned shoes/ Not a softness anywhere about me/ Only whale-bone and brocade/And I sink on a seat in the shade/ Of a lime tree/ For my passion/ Wars against the stiff brocade/ The daffodils and squills/ Flutter in the breeze/ As they please/And I weep/ For the lime tree is in blossom/ And one small flower has dropped upon my bosom (Lowell, 1917, lines 1-30). 
Life as the greatest pattern before her now lies broken as she is unable to express her emotional hunger for her dead lover before it is too late. In a way, her frustration is revealed through the vivid images of nature juxtaposed with the fixed structures of society.

Gone with the Wind (1939) by Margaret Mitchell depicts life in American South in, after and during the Civil War (18611865). The novel tells the struggle of Scarlett O'Hara who feels the responsibility to bring back order, prosperity and tranquility to Tara, her plantation home in Georgia because all men have left for the war. Brought up as the typical Southern Belle, Scarlett O'Hara represents the so-called society norms of femininity such as delicacy, beauty and nobility. However, she transforms from the expected Southern Belle to a more selfish, opportunist and self-reliant female through the end of the novel. Mitchell portrays Scarlett almost through her clothes and it is always her dresses that speak for her. For instance, under hot Georgia sun, in 17 inch corseted flamboyant dresses with her Mammy tight-lacing her, O'Hara complains about the rigid structures of custom enforced upon her body:

Hole onter sumpin' an' suck in yo breaf (Mammy) commanded. Scarlett obeyed, bracing herself and catching firm hold of one of the bedposts. Mammy pulled and jerked vigorously and as the tiny circumference of whalebone girdled, waist grew smaller, a proud, fond look came into her eyes (GWW, Chp 5, p.33-34).

Scarlett is not fond of the restrictive roles of femininity imposed upon herself both by clothes and customs, however she does not confront them either. Especially, she feels like she has to look charming when she meets men to please them so she uses the window curtain to dress herself like a lady when she has nothing to wear during war times: "The cock feathers gave her a dashing air and the dull-green velvet of the bonnet... And the dress was incomparable, so rich and handsome looking and yet so dignified!" (GWW, Chp 34, p.537). According to Stephen Mandravelis, as a plot device, the green curtain dress embodies deception. Crafted by a hungry, broke, and distressed Southern belle from the last vestige of refinement at her plantation, the dress feigns Southern respectability. Scarlett masquerades curtains as a dress to mask her own desperation. It is a romantic symbol of perseverance and self-determination, representative of a bygone era. This green curtain dress is a paradox; an object caught oscillating between its two existences. (2013-2015). Despite her enslavement through her corseted dresses, Scarlett uses clothes on her benefit, either to please or to persuade men; or to portray the Old South values in a huge, decaying mansion.

The last example for the depiction of women through dress belongs to FS Fitzgerald's famous work. The Great Gatsby (1925). The novel is a great work of fiction which displays the 1920s through a story of money, success, fun, fame and decadence. It is believed that Fitzgerald has designed the Flapper type of female identity mostly taking after his beautiful wife Zelda, who is reflected by the heroine, Daisy Buchanan in the book. The Jazz Age fashion is a remarkable element in the portrayal of characters who speak through their dresses and accessorizes more than their words:

Suddenly, with a strained sound, Daisy bent her head into the shirts and began to cry stormily."They're such beautiful shirts," she sobbed, her voice muffled in the think folds. "It makes me sad because l've never seen such - such beautiful shirts before." (GG, Chp.5, p.118-119)

Short, colorful dresses (which help them dance feely) with silk stockings and bonnets on short hair with long cigarette holders defined woman's fashion whereas pink suits for men could be observed in that era. In the novel, it is not their corseted bodies that restrict women -as there is loose corsetry or no corsetry at all, but the codes of the newly rich that determine one's status and popularity in society. In the huge mansion of Gatsby, it is not old money or education which is prized but the extravagant Saturday night parties where women shine like a diamonds and flow through champagne. The women in the novel are fashioned perhaps in the most liberated style than before; nevertheless they feel restless, bored and restricted.

\section{Conclusion}

Going back to the claims of Elizabeth Wilson and Roland Barthes stated in the beginning of this article, clothes represent the mood of each succeeding age and what we do with our bodies express the Zeitgeist. In that fashion, dress is a social text to be read with signs in certain rhetoric. So, corsetry is claimed as one of the popular garments of a social condition and the prevailing sign of a specific fashion. Therefore, this study centers on the significance, uses and changes of the corset in the Western culture and literature from its early usages up to contemporary time through the politics of body and fashion. In that way, the study of corsetry is aimed to unveil the ways ideology co-operates with fashion to define the beauty standards and help create the idealized (female) image as a cultural construct in Western society. 
With these in mind, it is observed that the corset works both as a controlling and subversive device which is necessary in socialization and sexualization of the female body (Summers, 2001, p.63). The corset idealizes and also restricts the female form as an object of ruling ideology. However in its contemporary usages, it has been perceived in symbolic contexts, where the garment is deconstructed as a part of sub-culture fashion or has become a commodified entity to be displayed or used as stage-prop on catwalk. Demystification of corsetry can be explained by the contemporary feminist critic Naomi Wolf (2002) who claims that the corset now is replaced by the new control devices of patriarchal culture such as plastic surgery, diet and extreme physical exercise. This shows that Western patriarchal culture still has a lot to shape and correct, deciding what it is beautiful, proper and accepted and what is not.

\section{References}

[1] Aspinall, Hannah, (2012). The Fetishization and Objectification of the Female Body in Victorian Culture, Brighton Online Journal. [Online] Available: http://arts.brighton.ac.uk/study/literature/brightonline/issuenumber-two/thefetishization-and-objectification-of-the-female-body-in-victorian-culture (Sept 12, 2017).

[2] Barnard, Malcolm, ed., (2007). Fashion Theory: A Reader, UK: Routledge.

[3] Barthes, Roland, (2013). The Language of Fashion, UK: Bloomsbury.

[4] Bender, A., (1997-2016). A Short History of the Corset, Marquise.de Website. [Online] Available: http://www.marquise.de/en/themes/korsett (Sept 12, 2017).

[5] Blakemore, Erin, (2014). The Gibson Girls: The Kardashians of the Early1900s.[Online] Avaliable:http://mentalfloss.com/article/58591/gibson-girls-kardashians-early-1900s. (Sept 12, 2017).

[6] Bland, M. Susan, (1983). Henrietta the Home-maker: Images of Women in Advertising. Regina Public Library. [Online] Available: file:///C:/Users/sony/Downloads/4531-5948-1-PB.pdf (Sept 12, 2017).

[7] Bordo, Susan, (1993). Unbearable Weight: Feminism, Western Culture and the Body, Berkeley: University of California Press.

[8] Butler, Judith, (2011). Bodies That Matter, UK: Routledge.

[9] Caelleigh, Addeane S, (1998). Too Close for Comfort: 500 Years of Corsets Fashion and Folly in Corsets and Shoes. [Online] Available: http://exhibits.hsl.virginia.edu/clothes/ (Sept 12, 2017).

[10] Corsets and Bustles from 1880-90: the Move from Over Structured Opulence to the Healthy Corset, (2016), Victoria\&Albert Museum Archives. [Online] Avaliable:http://www.vam.ac.uk/content/articles/t/the-corset-inlate-20th-century-fashion/ (Sept 12, 2017).

[11] Eby, Clare Virginia, (1992). Silencing Women in Edith Wharton 's The Age ofInnocence, Colby Quarterly, Volume 28, no.2, p.93-104.

[12] Entwistle, Joanne and Elizabeth Wilson, (2001). Introduction. Body Dressing: Dress, Body and Culture, Eds. Joanne Entwistle and Elizabeth Wilson, NY: Berg, 1-13. [Online] Available: https://tr.scribd.com/doc/156959017/Body-Dressing (Sept 12, 2017).

[13] Foucault, Michel, (1972). Part Three, Discipline: Docile Bodies. Discipline and Punish. 2nd Ed. Vintage Books, 1995: 135-169. [Online] Available: http://isites.harvard.edu/fs/docs/icb.topic1114853.files/Foucault\%201977.pdf(Sept 12, 2017).

[14] Glasscock, Jessica, (2004). Eighteenth Century Silhouette and Support. HeilbrunnTimeline of Art History. NY: MET, 2000-.[Online] Available: http://www.metmuseum.org/toah/hd/18sil/hd_18sil.htm, (Sept 12, 2017).

[15] Irigaray, Lucy, (1985). Speculum of the Other. Trans. Gillian C Gill, NY: Cornell.

[16] James, Henry (1881). The Portrait of a Lady. [Online] Available: http://www.literaturepage.com/read/portraitof-a-lady.htm (Sept 12, 2017).

[17] Johnstone, Lucy, (2016). Corsets \& Crinolines in Victorian Fashion. Victoria\&Albert Museum Archives. [Online] Available: http://www.vam.ac.uk/content/articles/c/corsets-and-crinolines-in-victorian-fashion/ (Sept 12, 2017).

[18] Kiter, Tammy, (2016). The Ties that Bound: Corset Controversy in the Victorian Era. NY Historical Society Website, December 29. [Online]. Available: http://blog.nyhistory.org/the-ties-that-bound-corset-controversy-inthe-victorian-era/ (Sept 12, 2017).

[19] Kunzle, David, (1982). Fashion and Fetishism: A Social History of Corsets, Tight Lacing and Other Forms of Body Sculpture in the West, NJ: Rowman and Littlefield.

[20] Lowell, Amy, (1917). "Patterns," [Online] Available: https://www.poetryfoundation.org/poems/42987/patterns (Sept 12, 2017).

[21] Mahe, Yvette, (2013). History of Women's Corsets. Fashion and Time Webstite. [Online] Available: http://www.fashionintime.org/history-of-womens-corsets-part-1/ (Sept 12, 2017). 
[22] Mandravelis, Stephen, (2013-2015).Scarlett's Green Curtain Dress. The Southern Things. [Online] Available: http://southernthings.web.unc.edu/scarletts-green-curtain-dress/ (Sep 12, 2017).

[23] Mitchell, Margaret, (1936). Gone with the Wind. [Online] Available: http://biblioteka.kijowski.pl/mitchell\%20margaret/gone\%20with\%20the\%20wind.pdf (Sept 12, 2017).

[24] O' Donoghue, Kathryn Erin, (2015). Loosening the Critical Corset: New Approaches to the Short Fiction of Kate Chopin and Ruth Stuart. [Online] Available: http://academicworks.cuny.edu/cgi/viewcontent.cgi?article=1600\&context=gc_etds. (Sept 12, 2017).

[25] Roberts, Jacob (2017). Women'sWork. Distillations. 3 (1): 6-11. [Online] Available: https://www.chemheritage.org/distillations/magazine/womens-work (Sept 12, 2017).

[26] Soper, Kate, (2001). Dress Needs: Reflections on the Clothed Body, Selfhood and Consumption. Body Dressing: Dress, Body and Culture, Eds. Joanne Entwistle and Elizabeth Wilson, NY: Berg, 19-32. [Online] Available: https://tr.scribd.com/doc/156959017/Body-Dressing (Sept 12, 2017).

[27] Spooner, Catherine, (2004). Fashioning Gothic Bodies. UK: Manchester UP.

[28] Steele, Valerie, (1996).Fetish: Fashion, Sex and Power, NY: Oxford UP.

[29] Steele, Valerie, (2001).The Cultural History of the Corset, NY: Yale UP.

[30] Summers, Leigh, (2001). Bound to Please, Oxford: Berg.

[31] The Corset in Late 20th-Century Fashion, (2016), Victoria\&Albert Museum Archives. [Online] Avaliable:http://www.vam.ac.uk/content/articles/t/the-corset-in-late-20th-century-fashion/ (Sept 12, 2017).

[32] Thomas, Pauline W, (2001-2014). Early Corsetry and Fashion History. [Online] Available: http://www.fashionera.com/early_corsetry.htm (Sept 12, 2017).

[33] Veblen, Thorstein, (1899). The Theory of the Leisure Class. [Online] Available: http://moglen.law.columbia.edu/LCS/theoryleisureclass.pdf. (Sept 12, 2017).

[34] Werlin, Kathy and the Fashion Historian, (2010-2017). The Chemise a la Reine. [Online]. Available: http://www.thefashionhistorian.com/2012/03/chemise-la-reine.html) (Sept 12, 2017).

[35] Wharton, Edith, (1905). The House of Mirth. [Online] Available: http://www.gutenberg.org/files/284/284h/284-h.htm(Sept 12, 2017).

[36] Wharton, Edith, (1920). The Age of Innocence. [Online] Available: http://www.gutenberg.org/files/541/541h/541-h.htm (Sept 12, 2017).

[37] Wilson, Elizabeth, (2003). Adorned in Dreams, NY: Rutgers UP.

[38] Wolf, Naomi. The Beauty Myth. NY: Harper, 2002.

[39] Woodward, Sophie, (2002). Making Fashion Material, Journal of Material Culture, Vol. 7(3), London: Sage, 345-353. 